\title{
Introducing environmental thresholds into water withdrawal management of mountain streams in the Kura River basin, Azerbaijan
}

\section{R. K. ABBASOV \& V. U. SMAKHTIN}

To cite this article: R. K. ABBASOV \& V. U. SMAKHTIN (2009) Introducing environmental thresholds into water withdrawal management of mountain streams in the Kura River basin, Azerbaijan, Hydrological Sciences Journal, 54:6, 1068-1078, DOI: 10.1623/hysj.54.6.1068

To link to this article: https://doi.org/10.1623/hysj.54.6.1068

曲 Published online: 19 Jan 2010.

Submit your article to this journal $₫$

III Article views: 357

Q View related articles ¿

Citing articles: 3 View citing articles $₫$ 


\title{
Introducing environmental thresholds into water withdrawal management of mountain streams in the Kura River basin, Azerbaijan
}

\author{
R. K. ABBASOV ${ }^{1}$ \& V. U. SMAKHTIN ${ }^{2}$ \\ 1 Hydrometeorological Research Institute, Ministry of Ecology and Natural Resources, 50 H.Aliyev, \\ AZ 1154, Baku, Azerbaijan \\ abbasov@hotmail.com \\ 2 International Water Management Institute, PO Box 2075, Colombo, Sri Lanka
}

\begin{abstract}
The study aims to set and implement environmentally relevant limits for the exploitation of mountain streams in the Kura River basin of Azerbaijan. Such streams represent the preferred spawning grounds for valuable sturgeon of the Caspian Sea, but experience continuously increasing exploitation in the form of water withdrawals for industry and irrigation. Since no detailed environmental flow assessments have been conducted on any of the Kura basin streams, an interim approach is suggested based on minimum flow, referred to as "base environmental minimum". The latter may be estimated from the unregulated parts of observed or simulated daily flow records. Environmental flow requirements for individual months of an individual year may be calculated using correction factors related to monthly rainfall. Simple relationships are suggested for base environmental flow estimation at ungauged sites, and the implications of river pollution for monthly environmental requirements are examined. Further, definition of environmentally critical periods in a stream is proposed based on a ratio of observed to "environmental" flow as an indicator of environmental stress. It is illustrated that the conjunctive use of several closely located streams for water supply may significantly reduce the duration of, or completely eliminate, environmentally critical periods. The idea of environmentally acceptable areal water withdrawal is formulated, so that the overall approach may be applied for environmentally sustainable water withdrawal management in other small streams.
\end{abstract}

Key words environmental flow; water withdrawals; ungauged basins; river pollution; environmentally critical periods; conjunctive water use

\section{Introduction de seuils environnementaux dans la gestion des prélèvements d'eau dans des ruisseaux montagneux du bassin versant de la Rivière Kura, Azerbaïdjan}

Résumé L'étude a pour objectif d'établir et d'implémenter des limites à vocation environnementale à l'exploitation des ruisseaux montagneux du bassin versant de la Rivière Kura en Azerbaïdjan. De tels torrents constituent les frayères préférées de l'esturgeon de la Mer Caspienne, mais subissent une exploitation en croissance constante sous la forme de prélèvements d'eau pour l'industrie et l'irrigation. Aucune évaluation précise de débit écologique n'ayant été menée pour les ruisseaux du bassin de la Kura, une approche provisoire est proposée sur la base d'un débit minimum, considéré comme étant la "base environnementale minimale". Cette dernière peut être estimée à partir des portions non-régulées des séries de débit journalier observées ou simulées. Les objectifs de débit écologique des mois particuliers d'une année particulière peuvent être calculés à l'aide de facteurs correctifs liés à la précipitation mensuelle. De simples relations sont proposées pour estimer le débit de la base environnementale en des sites non jaugés, et les implications de la pollution vis-à-vis des exigences environnementales mensuelles sont examinées. De plus, la définition de périodes écologiquement critiques d'un ruisseau est proposée sur la base d'un rapport entre débits observé et écologique, considéré comme un indicateur de stress environnemental. L'illustration est faite que l'exploitation conjointe pour l'alimentation en eau de plusieurs ruisseaux très proches peut réduire significativement, ou annuler complètement, la durée des périodes écologiquement critiques. L'idée d'un prélèvement zonal écologiquement acceptable est formulée, de telle façon que l'approche générale puisse être appliquée au service d'une gestion écologiquement durable des prélèvements d'eau dans d'autres petits ruisseaux.

Mots clefs débit écologique; prélèvements d'eau ; bassins versants non jaugés; pollution de rivière; périodes écologiquement critiques; utilisation d'eau conjointe

\section{INTRODUCTION}

The Kura River, together with its tributary Araks, forms the largest transboundary river system of the southern Caucasus. It originates in Turkey, and flows through Georgia and Azerbaijan into the Caspian Sea, while the Araks also crosses Armenia and Iran (Fig. 1).

Azerbaijan occupies primarily the downstream part of the Kura River basin. Its climate is continental, with dry summers and wet winters. The mean annual precipitation for the period 


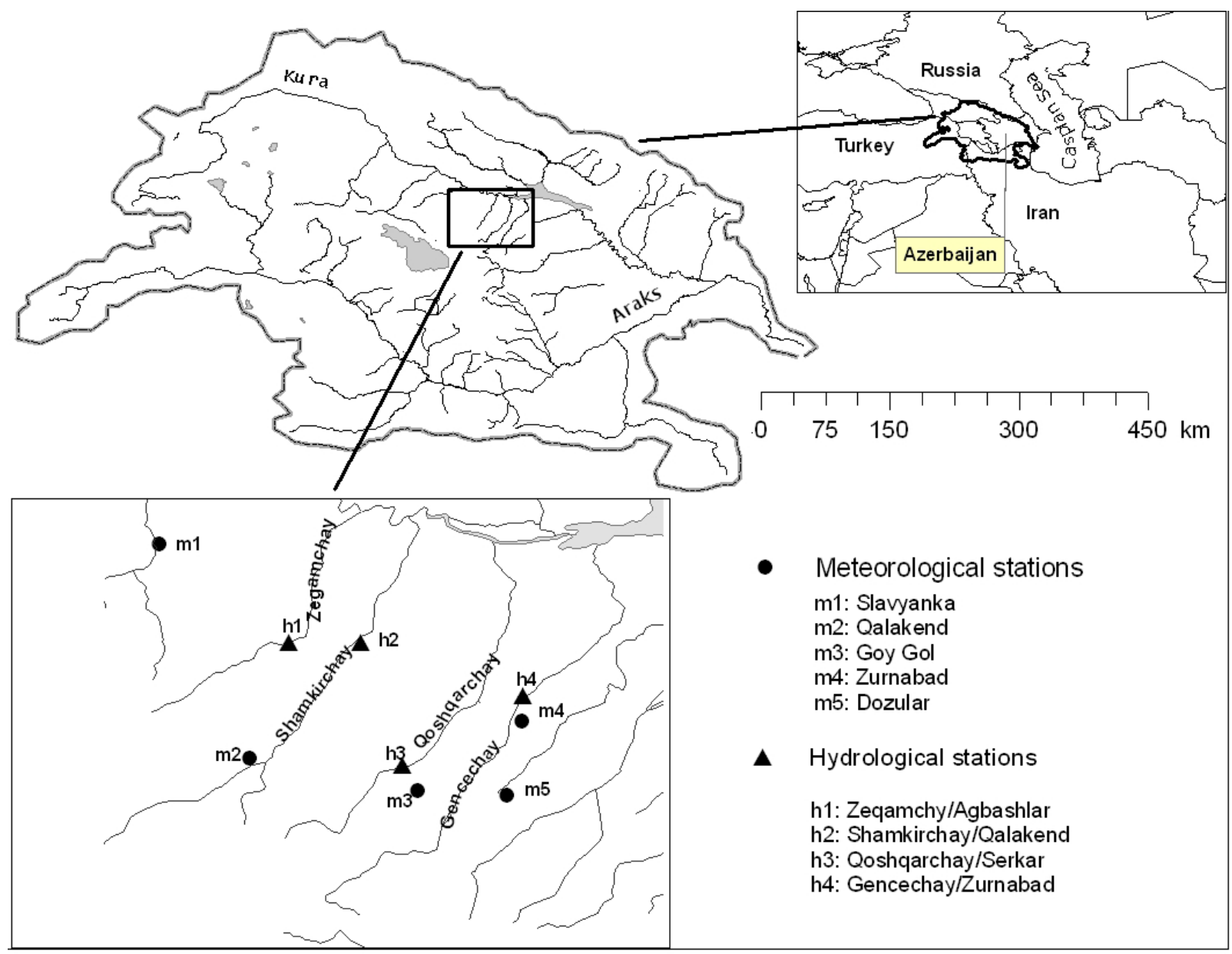

Fig. 1 Map of the Kura River basin and study area showing the streams and meteorological and hydrological stations referred to herein.

1961-1990 is estimated to be around 462 mm (HMSRI, 2008; Shiraliyev \& Mahmudov, 2008). Precipitation occurs mostly in winter. In the mountain regions, winter temperatures are below $0^{\circ} \mathrm{C}$ and winter precipitation is therefore usually in the form of a snow (Fatullaev, 2002). The period from April to October is predominantly rainless and, consequently, low river flows are observed from August to October (Imanov, 2003). Approximately $50-60 \%$ of the annual flow volume occurs during April-June, triggered by intensive snowmelt and spring rains (Mamedov, 1989; Shiraliyev \& Mahmudov, 2008). The Kura-Araks water resources are used for energy production, irrigation and domestic water supply. The total water withdrawals for primarily consumptive uses are around $16.5 \mathrm{~km}^{3}$, of which over $70 \%$ is for agricultural uses and some $25 \%$ for industrial purposes (Fatullaev, 2002; Demin, 2007). In the Kura-Araks lowland, with its extensive development of irrigated agriculture, rivers are effectively the only sources of water. There are four large dams on the Kura and two on the Araks. Some small reservoirs have also been built on the small mountain rivers, mainly for irrigation.

The mouths of small mountain rivers flowing into the Kura and Araks are the preferred spawning grounds for the valuable sturgeon fish of the Caspian Sea, which contains over $90 \%$ of the world's sturgeon population (Williot et al., 2002). The Caspian Environmental Programme specifies that future development of resources should be environmentally sustainable and that all natural resources, including fish, should be carefully managed and protected (CEP, 2002; Panin \& Mamaev, 2002). Beluga or European sturgeon (Huso-Huso), Persian sturgeon (A. persicus) and Russian sturgeon (A. gueldenstaedti) are the most valuable representatives of Caspian sturgeon 
(Billard \& Lecointre, 2001). These species mainly migrate to rivers in March-April and OctoberNovember, spawning on rocky grounds in the areas close to outlets (Ivanov et al., 1999). Another valuable fish in the Caspian Sea is the Caspian salmon, listed in the Red Books of Russia, Kazakhstan, and Turkmenistan. In Azerbaijan and Iran, it is now marked as a species with a sharply declining population (CEP, 2002). Caspian salmon migrate to the very sources of mountain streams, located at rather high altitudes.

Such rivers (e.g. Zegamchay, Gencechay and Shamkirchay) are under extreme pressure at present due to intensive water withdrawals for agriculture, particularly during the low-flow period, when some of them run dry - a situation which is not natural in this region. Intensive water withdrawals in many small streams have led to significant changes in flow regime downstream (Verdiyev, 2002). Reduced flows lead to siltation of riverbeds, which may lead to catastrophic flooding, although subsequent high flows are often not high enough to flush the accumulated silt from riverbeds (Abbasov \& Mahmudov, 2009). In addition, some of the small rivers are polluted by the mining industry of the Small Caucasus (Zonn, 2004).

The deteriorating conditions of the small mountain streams in the Kura-Araks basin on the one hand, and their high ecological significance on the other, urgently require the setting of some environmentally-relevant limits for their water use, as well as policies to enforce these limits. The problem is exacerbated by the absence of environmental water management traditions in the region, and lack of capacity to determine environmentally relevant flows - typical issues in many parts of the world (Tharme \& Smakhtin, 2003).

Environmental flow (Dyson et al., 2003; Acreman \& Dunbar, 2004; Smakhtin \& Anputhas, 2006) refers to the flow regime in a river that ensures conservation of the river ecosystem. Ideally such flows should be established through a detailed quantification of the relationships between flow changes and the conditions of ecosystem components. The quantitative understanding of links between aquatic ecology and hydrology is developing worldwide and requires significant casespecific field work. Many environmental flow assessment methods have been suggested over the past two decades, and a number of comprehensive reviews were written on this subject (e.g. Tharme, 2003; Acreman \& Dunbar, 2004). The methods range from complex holistic ones (which examine various aspects of aquatic ecosystems, require significant amounts of study-specific information and involve a multidisciplinary team of experts) to desktop hydrological methods (which are based primarily on hydrological indices or time series).

Methods to determine environmental flow allocations were developed in the former Soviet Union from the 1970s. They were mainly termed "sanitary flow" or "ecological flow"-for sanitary and fishery needs of the regulated river reaches (the term "sanitary" was used as a close synonym of "environmental"). Detailed information on the methodologies developed in the former Soviet Union is presented by Imanov (2003). These methods were essentially "hydrological", whereby some flow index, determined from the hydrological time series, was used as an indicator of "environmental flow". Gatillo \& Filipovich (1971) set the minimum "ecological" flow equal to $75-80 \%$ of the minimum monthly river flow. Shahov (1980) recommends calculating minimum "ecological" flow based on the specific energy of a stream, estimated using flow velocity and cross-sectional area and, hence, similar to hydraulic approaches or environmental flow assessment. Dubinina \& Kozlitina (2000) suggest that a discharge of 95\% probability of exceedence may be used as a proxy for setting environmental flow standards, although they provide little ecological justification for this. Overall, ecological justification of environmental river flows in the former Soviet Union has been limited, but they allow preliminary ecological thresholds to be set in the absence of detailed eco-hydrological studies and funds for them. This paper uses a similar hydrological approach to set preliminary environmental thresholds of water use in the specific context of small mountainous streams of the Kura River basin. However, the main focus of the paper is on how such thresholds can be introduced into the overall management of water withdrawals from small streams and how to use these thresholds to reduce the adverse impacts on aquatic ecology in data-scarce environments. 


\section{ESTIMATING ENVIRONMENTAL FLOW USING OBSERVED FLOW RECORDS}

The study employs one of the many hydrological indices as a substitute for an environmentally acceptable flow regime, which may be determined as more ecological information becomes available in the region in the future. The method allows such indices to vary in line with natural flow variability. The estimation is based on daily flow time series and includes several steps.

- A historical daily flow time series at a site is split into two periods - before and after major human impact on the flow regime. For a regulated small river, the first part may be represented by the period before the year of dam construction and the second part the period afterwards. The first part represents the natural flow regime and the second the regulated one.

- For each of the 12 calendar months during the "natural" flow period, the historical daily flow minimum, and the flow exceeded $99 \%$ of the time $\left(Q_{99}\right)$ are estimated. The lower of the two daily flow values for each calendar month is set as the "base environmental minimum" for that month.

- For any specific calendar month, the environmental flow is then estimated using the formula:

$$
Q_{\mathrm{env}}=\left(X_{i} / X\right) Q^{*}{ }_{\mathrm{env}}
$$

where $X_{i}$ is the basin precipitation from the beginning of October to the end of March for year $i, X$ is the long-term mean precipitation for this period and $Q^{*}{ }_{\text {env }}$ is the environmental minimum baseflow for a calendar month. The explanation of equation (1) is as follows. In practice, environmental flow should be defined for the coming year to reserve a definite quantity of flow in the river and, subsequently, to estimate the balance, which can be withdrawn from it. In the context of Azerbaijan, the water year is from April to March and most of the annual precipitation is observed in winter, i.e. from October to March. There is a direct relationship between winter rainfall and summer low flows in the region (Vladimirov, 1976; Imanov, 2003). However, correlation between winter rainfall and monthly low flows from April to March progressively decreases naturally. The introduction of a historical base minimum $\left(Q^{*}{ }_{\text {ec }}\right)$ aims to improve the accuracy of estimates with equation (1). Thus, in a simple way, equation (1) incorporates both an element of the flow forecast and the need to reserve more water for an aquatic ecosystem in wet years as opposed to drier ones. All monthly thresholds for the coming water year (April-March) may be set at the end of March in the previous year.

The application of this method requires a flow time series representative of natural flow conditions. Such time series for sites with large upstream catchment areas are limited in the southern Caucasus, as most available observations start from the 1930s when anthropogenic impacts on large river flows had already begun. However, small rivers in the region often have the required length of observations reflecting relatively natural flow. For example, observations on the Gencechay River (Fig. 1) began in 1928, while anthropogenic impacts started to manifest themselves in 1985, and observations on the Zegamchay River began in 1934, while major flow regime changes started to occur after massive withdrawals in 1978. Figure 2 shows environmental monthly flows for 1994 in the Zegamchay River at Agbashlar. Base environmental flows for calendar months have been determined using data from 1934 to 1978, when the flow in the Zegamchay can be considered natural. The Figure illustrates that even minimal environmental flows were not possible to satisfy in the river five months out of 12, while in four months out of seven when they can be satisfied, the mean flow was only marginally higher than the environmental requirement. Water withdrawals in drier months are normally higher due to intensive irrigation in summer and autumn, which, naturally, exacerbates the problem, reducing the spawning grounds for the sturgeon species, which represent a regional economic asset. 


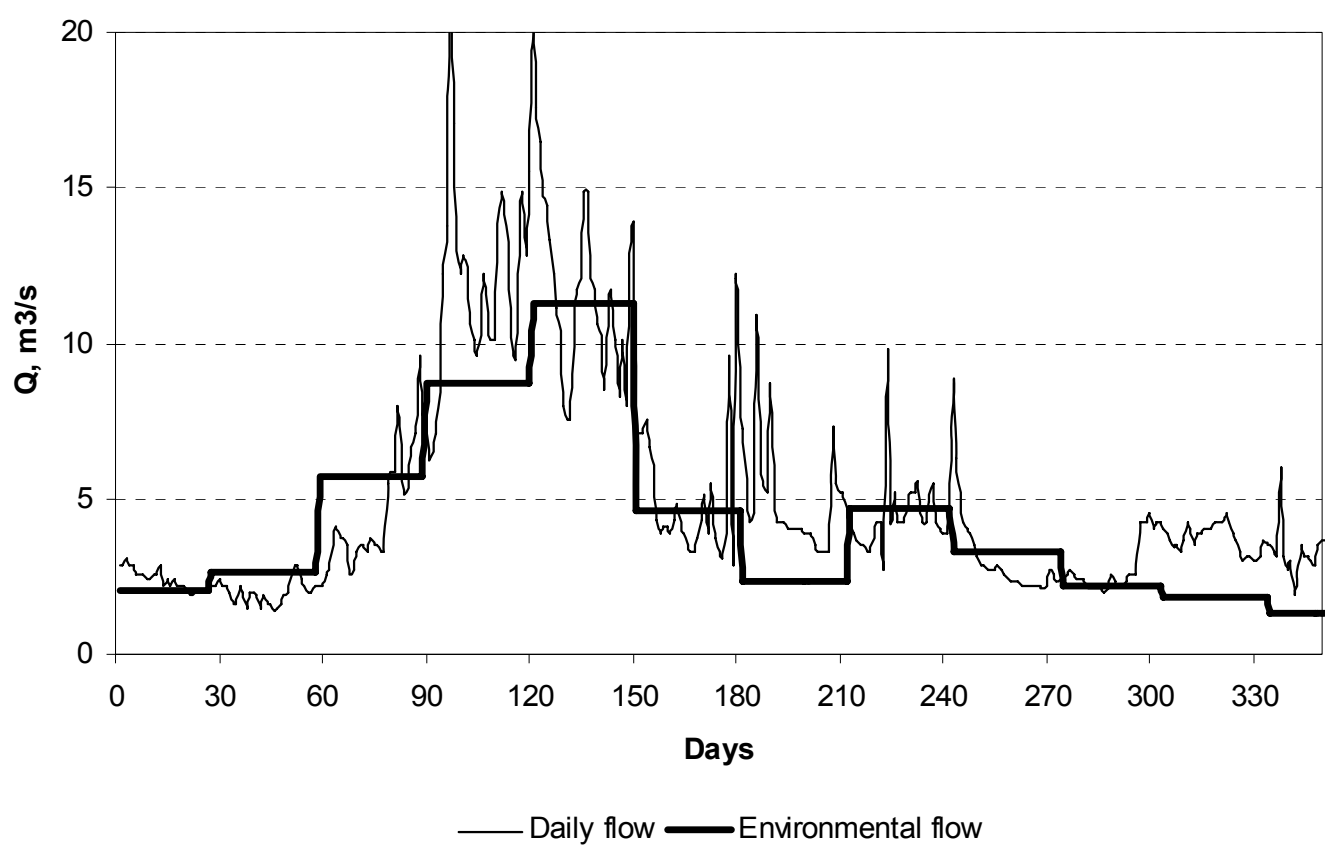

Fig. 2 Comparison of observed and environmental flows in the Zegamchay stream.

\section{ENVIRONMENTAL FLOW ESTIMATION IN POLLUTED STREAMS}

Some of the small streams of the Kura basin are highly polluted by the mining industry. Over the past 50 years, metal $(\mathrm{Cu}, \mathrm{Fe}, \mathrm{Al})$ concentrations in some streams have been increasing due to the growth of the mining operations in Azerbaijan and Armenia. Although recently many of these operations have stopped, the mines continue to be sources of pollution (Abbasov, 2005). Increased loads of pollutants in rivers adversely affect river ecosystems, and a water quality dimension should be added to setting and managing environmental water allocations.

A saying goes that "dilution is not a solution to pollution". Effluents should ideally be treated at source, before discharging into rivers. However, a common approach to the maintenance of river water quality in a reasonable condition is to dilute the pollutants (Cox, 1974; Pessen et al., 1986). The dilution capacity of receiving water is defined by the volume of water available for the dilution of effluent. Different pollutants require different dilution thresholds; the aim may be to dilute the pollutant with the highest concentration (SEPA, 1998).

In the case of polluted streams, the environmental flow estimated as explained above, should be increased so that:

$$
C / C_{\max } \leq 1
$$

where $C$ is the highest concentration of an individual pollutant and $C_{\max }$ the maximum acceptable concentration for the same. The increase in $Q_{\text {env }}$ should be in such proportion that the concentration of any pollutant does not exceed the maximum acceptable concentration level. The environmental flow of a polluted stream $\left(Q_{\text {env.con }}\right)$ should therefore be elevated by $Q_{\text {env }}$ so that:

$$
Q_{\text {env. con }}=\left(C / C_{\text {max }}\right) Q_{\text {env }}
$$

In natural conditions, the environmental flow can never exceed the observed flow, $Q_{\text {obs }}$, i.e.:

$$
Q_{\text {obs }}-Q_{\text {env.con. }} \geq 0
$$

Combining equations (3) and (4) leads to:

$$
Q_{\text {obs }} / Q_{\text {env }} \geq C / C_{\max }
$$

The ratio of observed to environmental flow should exceed $C / C_{\max }$. If this is not possible to achieve by dilution (increasing $Q_{\text {env }}$ ), the pollutant concentration $C$ must be reduced by water 
treatment at source prior to its disposal into the stream-a more appropriate water quality management practice. Alternatively, water withdrawals from the river upstream of the disposal site must be reduced to ensure higher flow downstream of it. The acceptable water withdrawal $\left(Q_{\mathrm{ww}}\right)$ is calculated as the difference between $Q_{\text {obs }}$ and $Q_{\text {env }}$ For polluted streams, $Q_{\text {ww }}$, is therefore determined as:

$$
Q_{\mathrm{ww}}=Q_{\mathrm{obs}}-\left(C / C_{\max }\right) \times\left(X_{i} / X\right) Q_{\mathrm{env}}
$$

\section{ESTIMATING ENVIRONMENTAL FLOW FOR UNGAUGED STREAMS}

Out of some 7000 rivers and streams in Azerbaijan, only a few have flow measuring stations with regular observations. Many gauging stations were closed due to the lack of funds after the collapse of the former Soviet Union. Most of the gauging stations (closed or still operating) are located on small streams - far from river outlets, which are particularly important for sturgeon spawning. Many previous studies imply that flow characteristics, such as various low-flow indices which may be indicators of environmental flow, depend on the catchment area (e.g. Vladimirov, 1976; Imanov, 2003). Figure 3 illustrates the dependence between base environmental flow $Q^{*}$ env for January and a catchment area using the data from several rivers in the Kura basin. Similar relationships have been established for all 12 calendar months of the year. The $R^{2}$ for such relationships ranges from 0.86 to 0.96 . Such relationships can be used to estimate $Q^{*}$ env for any ungauged site. This flow can then be converted to environmental flows in any month of the year using equation (1).

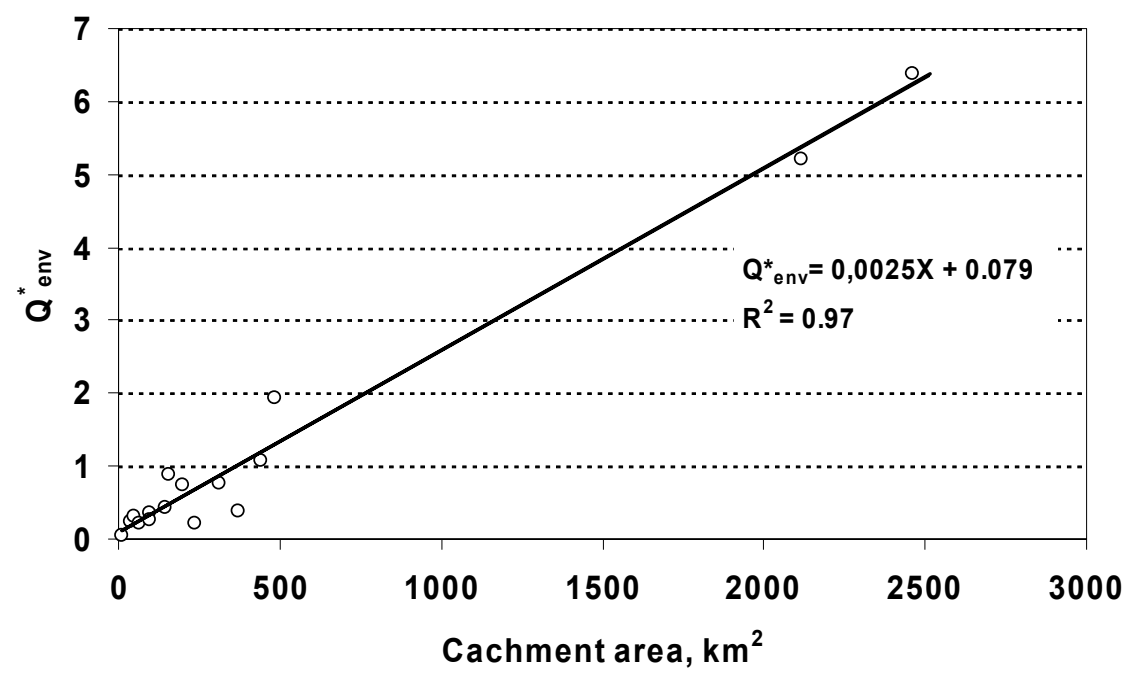

Fig. 3 Relationship of January base environmental flow with catchment area for the right tributaries of the Kura River.

\section{REDUCING ENVIRONMENTALLY CRITICAL PERIODS}

Deterioration of aquatic ecosystems, disturbance of riparian habitats or suspension of recreational activities can occur during extended ecologically critical periods - periods when actual observed flow is below an environmentally acceptable level. These periods can also be defined as a periods of unstable habitat, when the river ecosystem is under pressure due to lack of water. The Continuous-Under-Threshold (CUT) curve technique described by Capra et al. (1995) gives an opportunity to evaluate durations of unsuitable habitat under a specified threshold and to determine how long a given species can tolerate unsuitable conditions depending on its life stage. Critical periods can be shortened using management interventions. During such periods: 


$$
Q_{\mathrm{ww}}>Q_{\mathrm{obs}}-Q_{\mathrm{env}}
$$

A ratio of observed flow to environmental flow $(K)$ may serve as a simple indicator of the beginning and end of an environmentally critical period:

$$
K=Q_{\text {obs }} / Q_{\text {env }}
$$

If $K>1$, then there is enough water in a stream to satisfy ecosystem requirements. If $K<1$, an ecosystem may be said to be in the state of environmental water scarcity. For polluted streams, $K$ is determined as:

$$
K=Q_{\text {obs }} C_{\text {max }} / Q_{\text {env }} C
$$

Therefore, at the same discharge values, the environmentally critical period is longer in polluted streams than in non-polluted ones. Figure 4 shows the time series of $K$ values in the Zegamchay River at Agbashlar. If the stream is not polluted, the three major environmentally critical periods in 1994 (T1, T2, T3) would have the total duration of 102 days. In a polluted stream, the duration of individual critical periods and their total duration increase. For example, the total length of critical periods in the Qoshqarchay River at Serkar in 1994 is 35 days, but a twofold increase in pollutants extends this duration to 202 days (Fig. 5).

Usually, the beginning and the end of a critical period coincide with a low-flow period. However, even in nearby rivers, the beginning and end of low-flow periods and hence critical periods may differ. This allows critical periods to be reduced by simultaneous use of several sources of water to supply agricultural and municipal demand nodes. For example, if a demand node is located between the two different rivers, the water may be supplied from both of them rather then just one. This will decrease withdrawals from both rivers and thus shorten environmentally critical periods. The $K$ values in both rivers may be monitored, and withdrawal at any time allowed from the river whose $K$ value is higher. Figure 6 illustrates this point by showing the simultaneous time series of $K$ values for the Gencachay and Zegamchay rivers for the period from May 1994 to April 1995. During environmentally critical periods in the Zegamchay, there is enough water in the Gencechay, and therefore the latter can be used as the main water source during that period in the Zegamchay. The reverse is also true. Thus, the critical environmental periods $\mathrm{T} 1$ and $\mathrm{T} 2$ at Zegamchay can be completely avoided if during this period water is

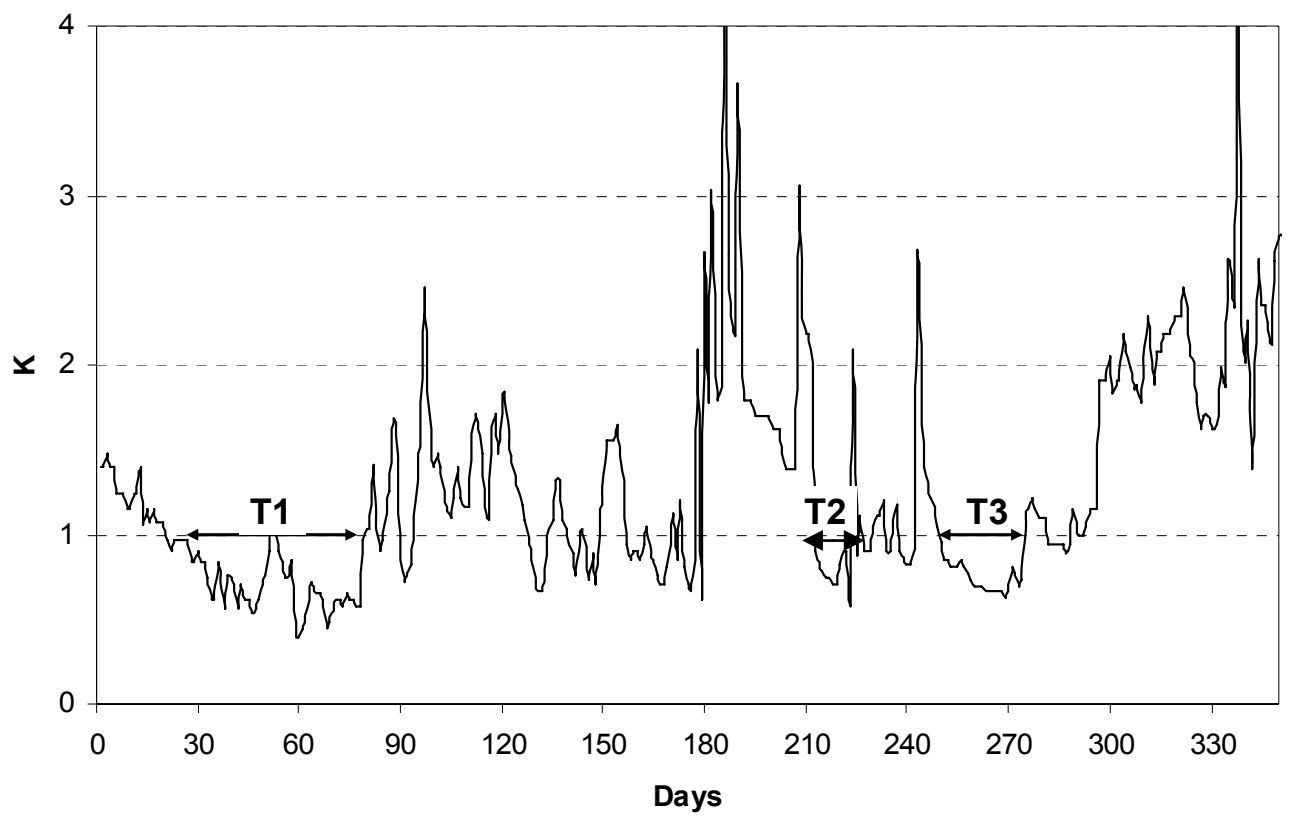

Fig. 4 Time series of $K$ in the Zegamchay River at Agbashlar, illustrating several ecologically critical periods. 


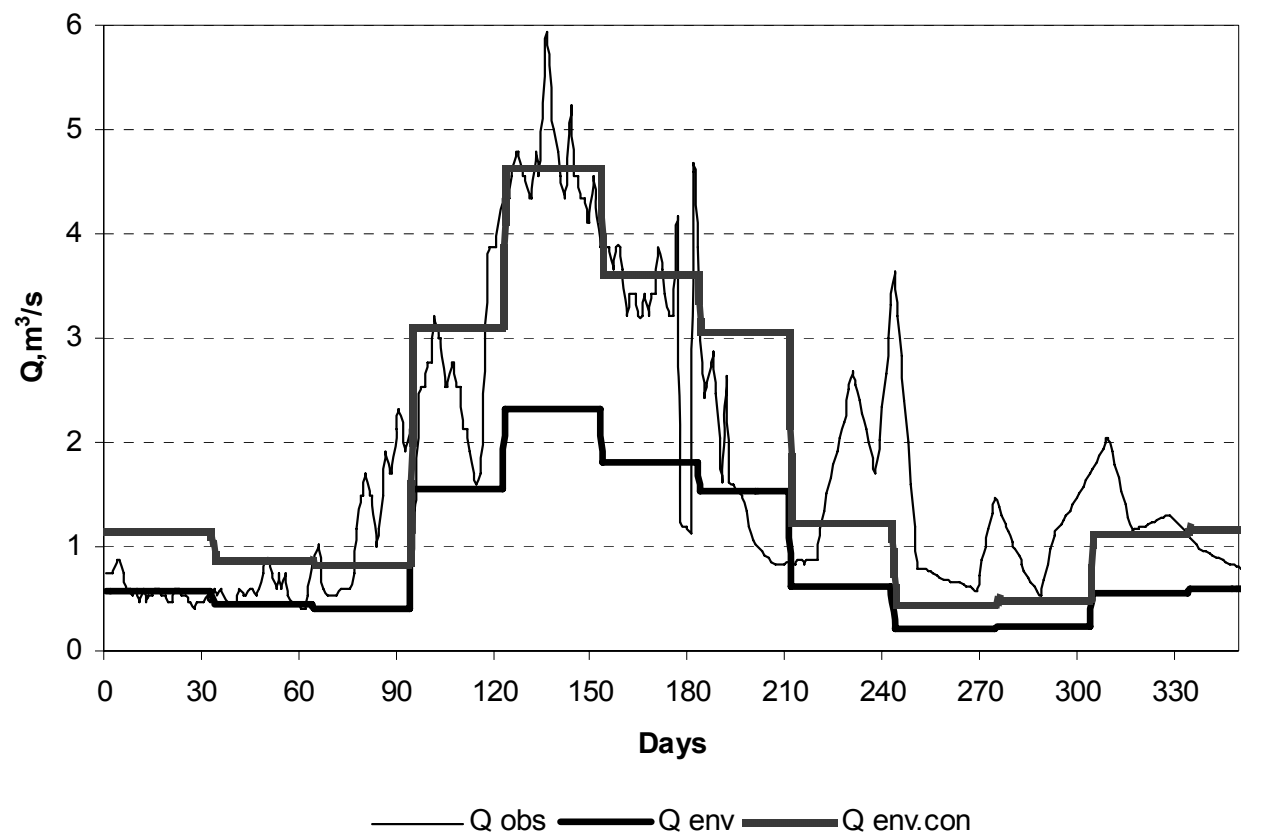

Fig. 5 Observed daily flows and environmental monthly flows in Qoshqarchay River at Serkar with and without consideration of pollution.

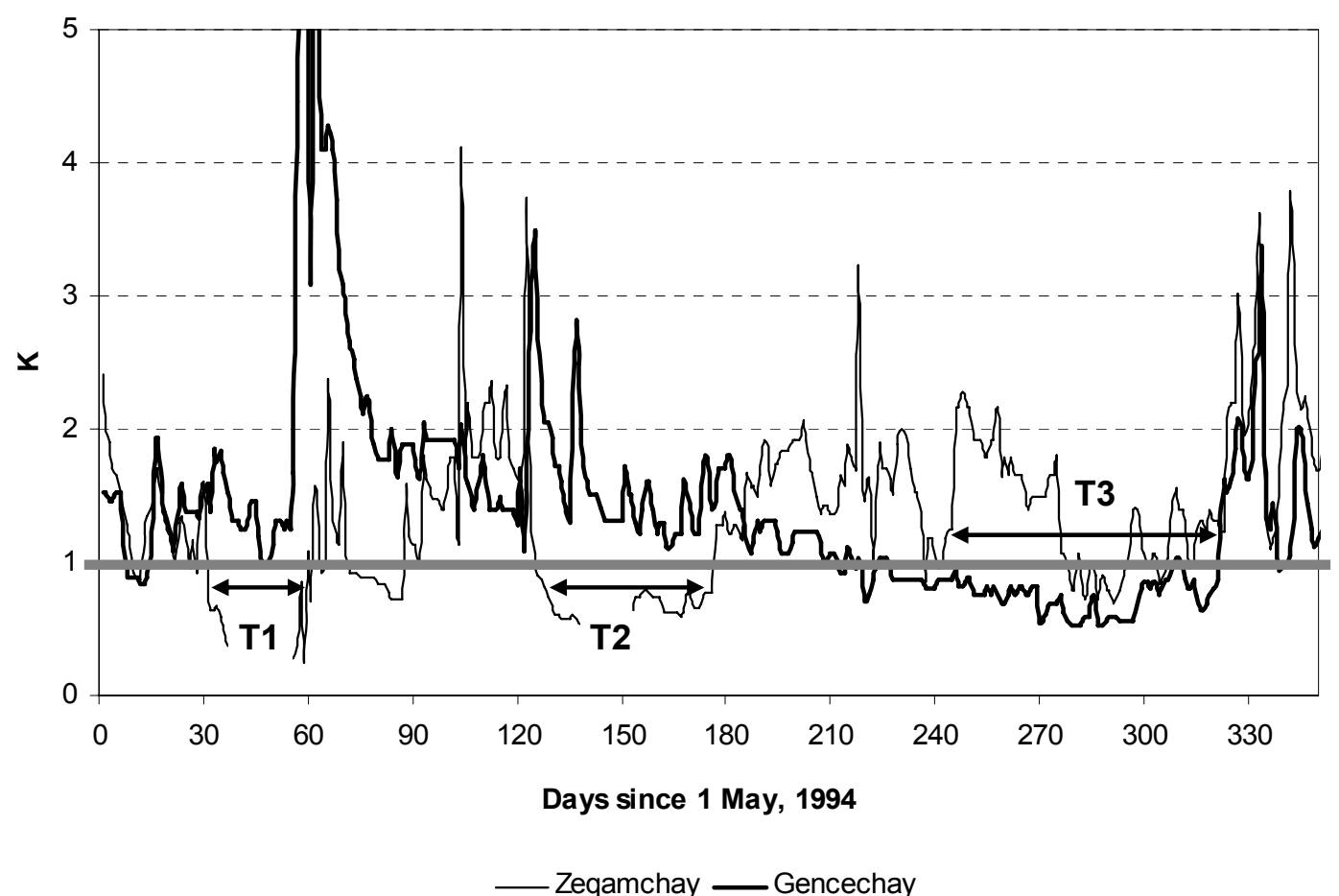

Fig. 6 The K time series in the Zegamchay River at Agbashlar and in the Gencechay River at Zurnabad in 1994-1995 showing some critical environmental periods, which may be decreased or eliminated by conjunctive use of water from both sources.

withdrawn from the Gencechay River instead. Similarly, most of the critical period T3 in the Gencechay River can be alleviated by using water from the Zegamchay River, where $K$ values are mostly above 1 at that time. This approach would allow the total length of critical periods to be reduced from 131 to 51 days and from 114 days to 63 days in the Zegamchay and the Gencechay 
Table 1 Reducing the duration of critical periods using alternative sources of water.

\begin{tabular}{|c|c|c|c|c|c|}
\hline \multirow[t]{2}{*}{$\begin{array}{l}\text { Year } \\
\text { (May-April) }\end{array}$} & \multirow[t]{2}{*}{ River/site } & \multirow{2}{*}{$\begin{array}{l}\text { Total length of all } \\
\text { critical periods (days) } \\
\text { if a source is used } \\
\text { independently }\end{array}$} & \multicolumn{3}{|c|}{$\begin{array}{l}\text { Total length of all critical periods (days) } \\
\text { during conjunctive use }\end{array}$} \\
\hline & & & Two sources & Three sources & Four sources \\
\hline \multirow[t]{4}{*}{ 1993-1994 } & Zegamchay/ Agbashlar & 156 & 71 & 3 & 0 \\
\hline & Qoshqarchay/Serkar & 147 & 60 & 0 & 0 \\
\hline & Shamkirchay/Kalakend & 51 & 21 & 14 & 0 \\
\hline & Gencechay/Zurnabad & 126 & 69 & 8 & 6 \\
\hline \multirow[t]{4}{*}{ 1994-1995 } & Zegamchay/ Agbashlar & 131 & 51 & 0 & 0 \\
\hline & Qoshqarchay/Serkar & 132 & 59 & 0 & 0 \\
\hline & Shamkirchay/Kalakend & 44 & 19 & 19 & 0 \\
\hline & Gencechay/Zurnabad & 114 & 63 & 4 & 4 \\
\hline \multirow[t]{4}{*}{ 1995-1996 } & Zegamchay/ Agbashlar & 91 & 44 & 0 & 0 \\
\hline & Qoshqarchay/Serkar & 126 & 84 & 5 & 0 \\
\hline & Shamkirchay/Kalakend & 32 & 16 & 0 & 0 \\
\hline & Gencechay/Zurnabad & 99 & 45 & 16 & 10 \\
\hline
\end{tabular}

rivers, respectively. Further increase in the number of water supply sources for conjunctive use would reduce the length of the critical periods in each source even more. Table 1 illustrates this point using different combinations of conjunctive water use from a pool of four rivers shown in Fig. 1 in three arbitrarily selected years.

In order to identify alternative sources of water supply for conjunctive use, a detailed hydrological study of the territory is required. Choosing the most effective alternatives for conjunctive use implies the consideration of such parameters as natural flow discharges in different months of the year, the closeness of water sources to each other and to water demand node(s), as well as the levels of pollution in each source. The overall permissible withdrawal from a study area which has $n$ potential water supply sources can, at any time, be estimated using the formula:

$$
Q_{\mathrm{ww}}=\sum_{1}^{n}\left(Q_{i}-Q_{\mathrm{env}, i}\right)
$$

where $Q_{i}$ are discharges in these sources and $Q_{\text {env }, i}$ are their corresponding environmental flows. The permissible volume of withdrawal can be estimated by simply multiplying equation (10) above by the number of seconds in a time period. If the information on the actual water withdrawn from the area were available, it could be compared with the estimates of "environmentally permissible withdrawals" calculated using equation (10). Therefore, the above effectively represents a simple tool for monitoring of whether the "regional environmental water thresholds" are maintained.

\section{CONCLUSIONS}

The main purpose of this study has been to suggest pragmatic ways for setting environmentally relevant flow requirements for small rivers in the Kura basin, where eco-hydrological studies of rivers have not been undertaken to date and more complex environmental flow assessment methods could not be used. Environmental flow evaluation methods based on analysis of historical hydrological data have been proposed and evaluated using observed daily flow time series.

Simple solutions have also been proposed for estimation of environmental flows in ungauged rivers of the region through regression relationships of flow with the catchment area. Environmental flows in any month of any particular year (for gauged or ungauged sites) could be estimated using the base environmental flow and a correction factor reflecting the wetness of the specific month. It has also been illustrated that river pollution increases the required environmental flow standards - often to levels which cannot be satisfied given the existing and future water withdrawals - if only "dilution of pollution" is considered. 
The results illustrate that observed flows in small streams of the region can be lower than estimated environmental flow throughout large parts of every year. Thus, periods referred to in this paper as "environmentally critical periods" vary in length in every year and are observed not only in low-flow times, but also during periods of high flow. The duration of such critical periods is determined using the ratio between daily observed flows and monthly environmental flows. It is illustrated that the duration of critical periods increases in polluted streams.

The ratio of observed and environmental flows allows the duration of environmentally critical periods on gauged sites to be analysed. To examine environmentally critical periods at ungauged sites, it is necessary to simulate the reference (natural) daily flow times series at such sites first. The utilization of earlier suggested methods of data transfer using various spatial interpolation techniques (Hughes \& Smakhtin, 1996; Smakhtin \& Masse, 2000) may be considered for this purpose. Such methods are suitable for data-sparse regions, such as the Kura basin. However, information on water quality parameters will have to be obtained through field surveys.

It has been illustrated that the duration of critical periods in streams of the region can be reduced significantly, or, in some years, completely eliminated, if water withdrawals are spread out between them. Such environmentally sustainable conjunctive use of water implies that ratios of flow to environmental flow in such streams are continuously monitored and decisions on which source to withdraw water from at any time are based on which water source has these ratios in excess of 1 . It has also been illustrated how the total permissible water withdrawal from an area can be estimated, using the estimated environmental flow standards.

Acknowledgements This work was partially supported by the Junior Facility Development Program of the Department of State, USA, and by the Hydrometeorological Research Institute of the Ministry of Ecology and Natural Resources, Azerbaijan. The data for the study were provided by the Hydrometeorological Department of Azerbaijan and by Michigan State University, USA. The authors are grateful to the Director of the Water Research Institute of the Michigan State University, Dr J. Bartholic, for reading the drafts of this paper. The constructive and helpful comments made by two anonymous reviewers are also gratefully acknowledged.

\section{REFERENCES}

Abbasov, R. K. (2005) Ecohydrological safety of flatland rivers. In: Theoretical and Practical Problems of Geology, 63-71 Scientific papers of the Geographical Society of Belarus, Minsk (in Russian).

Abbasov, R. K. \& Mahmudov, R. N. (2009) Analysis of non-climatic origins of floods in the downstream part of the Kura River, Azerbaijan. Natural Hazards 50, 235-248.

Acreman, M. C. \& Dunbar, M. J. (2004) Defining environmental flow requirements-a review. Hydrol. Earth System Sci. 5, 861-876.

Billard, R. \& Lecointre, G. (2001) Biology and conservation of sturgeon and paddlefish. Reviews in Fish Biology and Fisheries 10, 355-392.

Capra, H., Pascal, B. \& Souchon, Y. (1995) A new tool to interpret magnitude and duration of fish habitat variations. Regulated Rivers: Res. Manage. 10, 281-289.

CEP (Caspian Environment Programme) (2002) Transboundary diagnostic analysis for the Caspian Sea http://www.caspianenvironment.org (Last accessed: 12 April 2009).

Cox, J. L. (1974) The use of the dilution water effect as a water quality criterion. Bull. Environ. Contam. Toxicol. 11, 31-42.

Demin, A. P. (2007) Present-day changes in water consumption in the Caspian Sea basin. Water Resour. Res. 34(3), 237-253.

Dubinina, V. G. \& Kozlitina, S. V. (2000) Water resources management of the southern rivers of Russia with reference to fisheries requirements. Fisheries Manage. Ecology 7, 157-165.

Dyson, M., Bergkamp, G. \& Scanlon, J. (eds) (2003) Flow. the Essentials of Environmental Flows. IUCN, Gland, Switzerland and Cambridge, UK.

Fatullaev, G. Y. (2002) Current changes in water resources and water regime of South Caucasian rivers (within the Caspian Basin). Nafta Press, Baku, Azerbaijan (in Russian).

Gatillo, P. D. \& Filipovich, I. M. (1971) Questions of assessment of minimum necessary water flows of the rivers. In: Problems of Use of Water Resources, 26-42. The Collection of Scientific Works, Minsk, Russia (in Russian).

HMSRI (Hydrometeorology Scientific Research Institute, Azerbaijan) (2008) Climate and Natural Hazards of Azerbaijan in 2007: Meteorological Annual - resume. Hydromet Press, Baku, Azerbaijan.

Hughes, D. A. \& Smakhtin, V. U. (1996) Daily flow data time series patching or extension, a spatial interpolation approach based on flow duration curves.. Hydrol. Sci. J. 41(6), 851-871. 
Imanov, F. A. (2003) Minimum Water Flow of Caucasus Rivers. Nafta Press, Baku, Azerbaijan (in Russian).

Ivanov, P., Vlassenko, D., Khodorevskaya, P. \& Raspopov, M. (1999) Contemporary status of Caspian sturgeon (Acipenseridae) stock and its conservation. J. Appl. Ichthyology 15, 103-105.

Mamedov, M. A. (1989) Estimation of Maximum Flow Discharges in Mountain Rivers. Gidrometeoizdat, Leningrad, USSR (in Russian).

Panin, G. M. \& Mamaev, V. O. (2002) The Caspian Environmental Programme and the Caspian Research Network, Project of the Council of Europe. Water Resour. Res. 29(2), 233.

Pessen, D., Sinai, G. \& Reike, M. (1986) Design and simulation of water mixing junctions in irrigation systems. Int. J. Model. and Simul. 5(1), 33-41.

SEPA (Scottish Environmental Protection Agency) (1998) Regulation and Monitoring of Marine Cage Fish Farming in Scotland. A Procedures Manual. SEPA, Stirling, Scotland, UK.

Shahov, I. S. (1980) Methodology for calculating minimum ecological flow for the rivers of Ural Mountains. Scientific Papers of the Ural Institute of Water Management, vol. 11, 27-37.. Sverdlovsk (in Russian).

Shiraliyev, S. M. \& Mahmudov, R. N. (2008) Hydrometeorological Conditions and Natural Hazards in Azerbaijan. ZiyaNurlan Press, Baku, Azerbaijan

Smakhtin, V. U. \& Masse, B. (2000) Continuous daily hydrograph simulation using duration curves of precipitation index. Hydrol. Processes 14, 1083-1100.

Smakhtin, V. U. \& Anputhas, M. (2006) An assessment of environmental flow requirements of Indian river basins. IWMI Report no. 106, International Water Management Institute Research, Colombo, Sri Lanka.

Tharme, R. E. (2003) A global perspective on environmental flow assessment: emerging trends in the development and application of environmental flow methodologies for rivers. River Res. Applic. 19, 397-441.

Tharme, R. E. \& Smakhtin, V. U. (2003) Environmental flow assessment in Asia: capitalizing on existing momentum. In: Proc. First Southeast Asia Water Forum (17-21 November 2003, Chiang Mai, Thailand), vol. 2, 301-313. Thailand Water Resources Association, Bangkok, Thailand.

Verdiyev, R. G. (2002) Water Resources of Eastern Caucasus Under Climate Changes. BGU Press, Baku, Azerbaijan (in Russian).

Vladimirov, A. M. (1976) River Flow During Low-flow Period. Gidrometeoizdat, Leningrad, USSR (in Russian).

Williot, P., Arlati, G., Chebanov, M., Gulyas, T., Kasimov, R., Frank, K., Patriche, N., Pavlovskaya, L., Poliakova, L., Pourkazemi, M., Kim, Y., Zhuang, P. \& Zholdasova, I. (2002) Status and management of Eurasian sturgeon: an overview. Int. Rev. Hydrobiol. 87, 483-506.

Zonn, I. S. (2004) Caspian Encyclopedia. Mezhdunarodnye Otnosheniya, Moscow, Russia (in Russian).

Received 7 April 2008; accepted 2 July 2009 